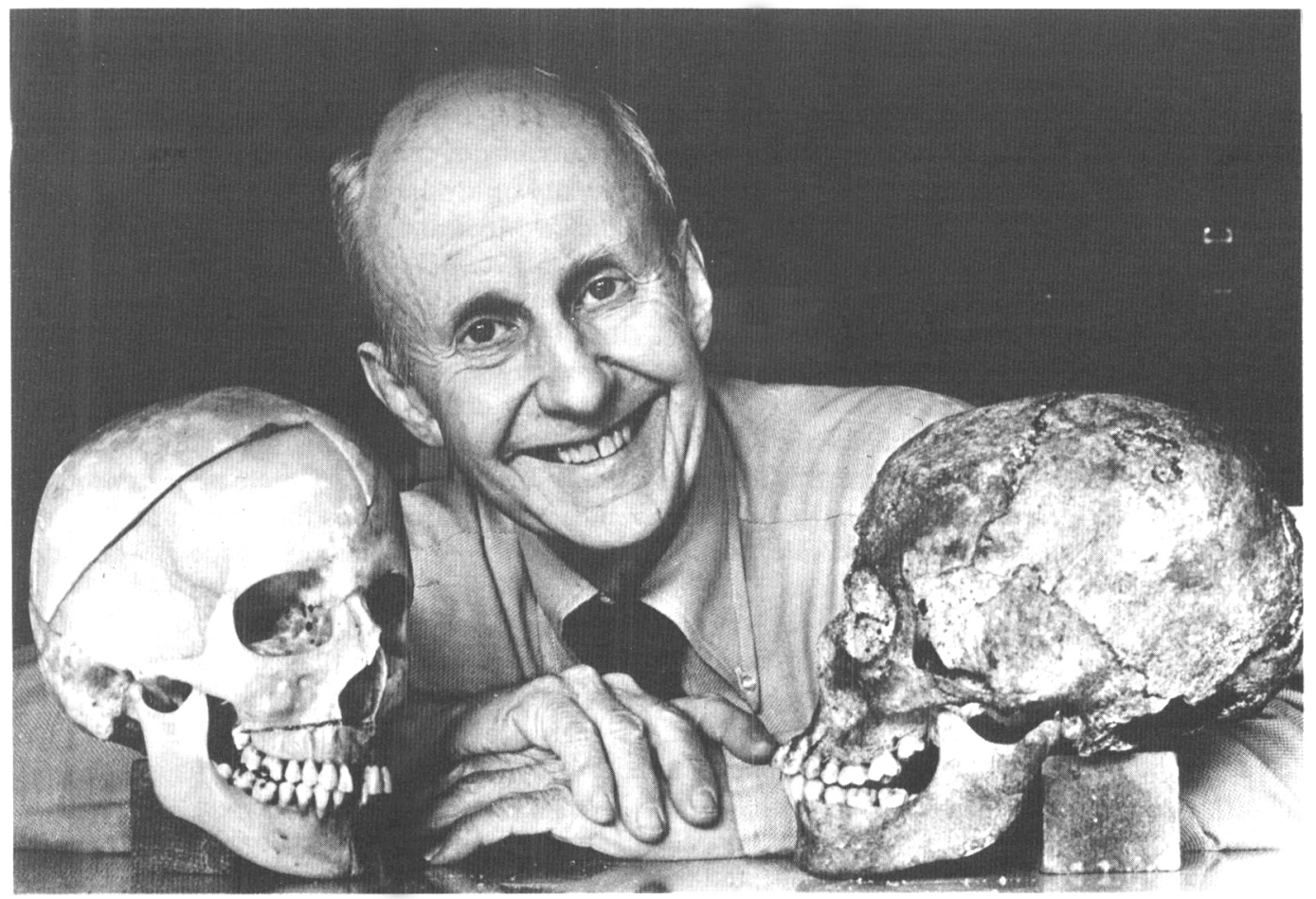

\title{
J. LAWRENCE ANGEL
}

1915-1986

On November 3, 1986, J. Lawrence Angel died at George Washington University Hospital at the age of 71 from complications resulting from hepatitis. Larry worked enthusiastically on research and teaching projects until the day he entered the hospital and even there confided to visitors that he fully expected to recover and continue his work. His attitude of enthusiastic dedication pervaded his entire career and remains an inspiration to all who worked with him.

J. Lawrence Angel was born on March 21, 1915, in London, England, the son of John Angel, a sculptor from Devonshire, England, and Elizabeth Day Seymour, an American classicist from Ohio, with family roots in Connecticut. Larry's early education was in England at Ovingdean School in Sussex. At the age of 13, Larry traveled to the United States and attended Choate School in Wallingford, Connecticut. An active and brilliant student, Larry enrolled in Harvard College, where in 1936 he graduated with an A.B. degree, Magna Cum Laude, Phi Beta Kappa. Larry chose Harvard University for graduate training, working primarily under Earnest Hooton. Through diverse course work and archaeological fieldwork in New Mexico, Arizona, Georgia, Greece, and Turkey, Larry received broad training in anthropology, but developed an intense intellectual commitment to the interpretation of the human skeleton and the geographic area of Greece and the Near East. Larry mentioned to me once that those interests were developed early in his life through curiosity about a human skeleton used in his father's sculptor studio and his mother's interest in the classics. Those

American Antiquity, 54(1), 1989, pp. 5-8.

Copyright (C) 1989 by the Society for American Archaeology 
interests were developed highly in graduate school and ultimately became the focus of his professional career. Also at Harvard, Larry discovered his great skill as a teacher where he assisted in teaching anthropology from 1939 to 1941 . He taught at the University of California, Berkeley, from 1941 to 1942 before receiving his Ph.D. from Harvard in 1942 with a dissertation on biocultural associations in ancient Greece. During his senior year at Harvard, he became acquainted with Margaret Seymour Richardson through Harvard-Radcliffe singing groups and in 1937 they began their 49-year marriage.

Following a one-year teaching position at the University of Minnesota, Larry joined the faculty of the Daniel Baugh Institute of Anatomy of the Jefferson Medical College in Philadelphia where he taught anatomy and conducted research from 1943 to 1962 . He returned to Greece in 1949 , 1954 , and 1957. During this period, Larry also worked as a civilian consultant in surgical anatomy to the United States Naval Hospital, Philadelphia, from 1957 to 1962, and began a career involvement with museums as a research associate at the University Museum of the University of Pennsylvania from 1946 to 1962 .

In 1962, Larry left Philadelphia for the Smithsonian Institution in Washington, D.C. Larry stated on occasion that he shifted to the Smithsonian mainly for increased research opportunity, an opportunity that he took full advantage of with seven career research trips to Greece and Turkey, and numerous trips to national and international meetings to present research papers. The latter was especially important to Larry, since in 1984 he noted he had presented papers at nearly all meetings of the American Association of Physical Anthropologists since joining the Association in 1940, most meetings of the American Academy of Forensic Sciences and Paleopathology Association, and many meetings of the American Anthropological Association, the American Association for the Advancement of Science, the International Congress of Anthropological and Ethnological Sciences, and the Archaeological Institute of America.

Larry's over 200 publications reflect his broad interests but focus primarily on the physical anthropology of the eastern Mediterranean, paleodemography, obesity, functional anatomy, and forensic anthropology. The Social Science and Science Citation Indexes register over four hundred citations of these publications. Larry's work in the eastern Mediterranean correlating physical characteristics and disease with such environmental variables as the presence of marshes and Anopheles mosquitos simply was brilliant. His crisp intellect and diligent research dramatically influenced techniques of paleodemography, sharpened our awareness of sampling limitations, and expanded our capabilities to extract information about the individual from the skeleton. Larry never abandoned the concept of typology, and religiously recorded the many measurements and observations taught to him by Hooton. Unlike many others, Larry used the typological approach in a broad biocultural context with an astute sense of variation and of the impact of sampling problems. His pioneer work in the Near East has opened the door to understanding the biological history of the area and has stimulated many other scholars to continue his work. In 1983 The Archaeological Institute of America awarded Larry the Pomerance Medal in recognition of his outstanding contributions to Near Eastern studies.

At the time of his death, Larry Angel probably was known best for his contributions to forensic anthropology. Dubbed "Sherlock Bones" by the press, Larry frequently was in the news and was the subject of feature articles by Science Digest, Smithsonian Magazine, The Washington Post, and People Magazine. His interest in forensic work is not apparent in his record until he joined the Smithsonian staff in 1962 and assumed heavy casework for the FBI. However, from 1962 until his death in 1986, Angel reported on at least 565 forensic cases and testified as expert witness in 18 murder trials. Larry joined the American Academy of Forensic Sciences as a Provisional Member in 1975 and rapidly was promoted to Full Member in 1976 and to Fellow in 1978. He became a Board-Certified Diplomate in 1978 and went on to serve as President of the American Board of Forensic Anthropology from 1979 to 1984. In 1984, he received the Physical Anthropology Section award at the Annual Awards Banquet.

Angel's greatest contribution to forensic anthropology probably rests with his teaching. Informally, Larry constantly was teaching nearly everyone who happened by in all aspects of his research. This 
attitude attracted a long list of research assistants, volunteers, and colleagues who eagerly reached out for the information he offered. At a more formal level, Larry regularly lectured on forensic topics, taught physical anthropology at George Washington University each spring, and each fall taught a course in forensic anthropology primarily for forensic pathologists. As far as I know, the forensic course never was advertised, but each year there was a long wating list to attend. In 1984, Larry estimated that about 50 percent of medical examiners nationwide had taken his course. That is remarkable academic impact, considering his employment at the Smithsonian, a research institution normally not associated with teaching. I believe Larry would be delighted to know we continued that tradition in September of 1987 with a one-week intensive course in forensic anthropology. Once again we had more applicants than we could accommodate.

Larry Angel was a brilliant, productive anthropologist, but above all he was loved. We all loved the bow tie he always wore to meetings, the way he would continue a conversation even when you left the room, the big smile he would break out in the middle of an intellectual exchange, the way he would sing while collecting data on a skeleton, and the delight he took in placing the most odoriferous forensic case on the ledge outside the window in his laboratory with the window ajar just enough to arouse the curiosity of all who passed by. Larry was delightful, and we all miss him.

Acknowledgments. I gratefully acknowledge the assistance of the following persons in preparing this obituary: Margaret Angel of Bethesda, Maryland, and Stephanie Damadio, Caitlan Hawke, Katherine Murray, and Lawan Tyson of the Smithsonian Institution, Washington, D.C. The photograph was taken by Joel Richardson and is reproduced here courtesy of The Washington Post.

DOUGLAS H. UBELAKER

\section{SELECTED BIBLIOGRAPHY OF J. LAWRENCE ANGEL}

The following selection of Angel's publications are those most likely to be consulted by archacologists. A full bibliography by Douglas H. Ubelaker may be found in Angel's obituary by Lucille St. Hoyme in the American Journal of Physical Anthropology 75:294-301 (1988).

Angel, J. L.

1939 The Babaköy Skeleton. Archiv für Orientforschung 13:28-31.

1943 Treatment of Archaeological Skulls. Anthropological Briefs 3:3-8.

1945 Skeletal Material from Attica. Hesperia 14:279-363.

1946 Skeletal Change in Ancient Greece. American Journal of Physical Anthropology 4:69-97.

1946 Social Biology of Greek Cultural Growth. American Anthropologist 48:493-533.

1946 Some Interrelationships of Classical Archaeology with Anthropology. American Journal of Archaeology $50: 401$.

1950 Skeletons. Archaeology 3:233-241.

1951 Table 17. Belt Cave, Skull No. 2, Measurements, Indices, and Observations. In Cave Explorations in Iran, 1949, by C. S. Coon, pp. 86-88. Museum Monographs. The University Museum, Philadelphia.

1951 Troy: The Human Remains. Supplemental monograph to Troy Excavations Conducted by the University of Cincinnati 1932-1938, edited by C. W. Blegen. Princeton University Press, Princeton, New Jersey.

1952 The Human Skeletal Remains from Hotu Cave, Iran. Proceedings of the American Philosophical Society 96(3):258-269. Philadelphia.

1953 Classical Archaeology and the Anthropological Approach. In Studies Presented to David Moore Robinson on His Seventieth Birthday, edited by G. E. Mylonas and D. Raymond, pp. 1224-1231. Washington University, St. Louis.

1953 The Human Remains from Khirokitia. In Khirokitia, by P. Dikaios, pp. 416-430. Oxford University Press, London.

1954 La Cotte de St. Brelade II: Present Status (with C. S. Coon). Man 54(76):53-55.

1958 Human Biological Changes in Ancient Greece, with Special Reference to Lerna. Yearbook of the American Philosophical Society 1957:266-269.

1959 Early Helladic Skulls from Aghios Kosmas. In Aghios Kosmas: An Early Bronze Age Settlement and Cemetery in Attica, by G. E. Mylonas, pp. 167-169. University of Princeton Press, Princeton, New Jersey.

1961 Neolithic Crania from Sotira. In Sotira, by P. Dikaios, pp. 223-229. Museum Monographs. University Museum, Philadelphia.

1966 Appendix: Human Skeletal Remains at Karatas. American Journal of Archaeology 70:255-257.

1966 Early Skeletons from Tranquility, California. Smithsonian Institution Contributions to Anthropology 2(1). Smithsonian Press, Washington. 
1968 Ecological Aspects of Paleodemography. In The Skeletal Biology of Earlier Human Populations, edited by D. R. Brothwell, pp. 263-270. Pergamon Press, Oxford, England.

1969 The Bases of Paleodemography. American Journal of Physical Anthropology 30:427-437.

1970 Human Skeletal Remains at Karatas. American Journal of Archaeology 74:253-259.

1971 Early Neolithic Skeletons from Catal Huyuk: Demography and Pathology. Anatollian Studies 21:77-98.

1971 The People of Lerna, Analysis of a Prehistoric Aegean Population. Smithsonian Press, Washington, D.C.

1972 Ecology and Population in the Eastern Mediterranean. World Archaeology 4:88-105.

1972 Biological Relations of Egyptian and Eastern Mediterranean Populations during Pre-dynastic and Dynastic Times. Journal of Human Evolution 1:307-313.

1973 Human Skeletons from Grave Circles at Mycenae. In Ho Taphikos Kyklos V Ton Mykenon [The Grave Circle B of Mycenae], by G. E. Mylonas, pp. 379-397. The Archaeological Society of Athens, Greece.

1973 Neolithic Human Remains. Hesperia XLII:277-282.

1975 Human Skeletons from Eleusis. In The South Cemetery of Eleusis, by G. E. Mylonas, pp. 435-438. Library of the Archaeological Society of Athens, Greece.

1975 Paleoecology, Paleodemography and Health. In Population, Ecology, and Social Evolution, edited by S. Polgar, pp. 167-190. Mouton, The Hague.

1975 Porotic Hyperostosis, Anemias, Malarias, and Marshes in the Prehistoric Eastern Mediterranean. In Population: Dynamics, Ethics, and Policy, edited by P. Reining and I. Tinker, pp. 96-98. American Association for the Advancement of Science, Washington, D.C. Originally published 1966, Science 153:760763.

1976 Colonial to Modern Skeletal Change in the U.S.A. American Journal of Physical Anthropology 45:723735.

1977 Human Skeletons from Kephala. In Kephala: A Late Neolithic Settlement and Cemetery, by J. E. Coleman, pp. 133-156. American School of Classical Studies, Princeton, New Jersey.

1980 Late Stone Age Fishermen of Lothagam, Kenya (with T. W. Phenice, L. H. Robbins, and B. M. Lynch). Anthropological Series Vol. 3, No. 2. Michigan State University Museum, East Lansing.

1981 History and Development of Paleopathology. American Journal of Physical Anthropology 56:509-515.

1981 Physical Anthropological Analysis. In Archaeological Data Recovery at Catoctin Furnace Cemetery Frederick County, Maryland, by S. A. Burnston and R. A. Thomas, Appendix 2. Maryland Department of Transportation, Baltimore.

1984 Health as a Crucial Factor in the Changes from Hunting to Developed Farming in the Eastern Mediterranean. In Paleopathology at the Origins of Agriculture, edited by M. N. Cohen and G. J. Armelagos, pp. 51-73. Academic Press, New York.

1985 Health and Nutrition in Mycenaean Greece: A Study in Human Skeletal Remains (with S. C. Bisel). In Contributions to Aegean Archaeology: Studies in Honor of William A. McDonald, edited by N. C. Wilkie and W. D. E. Coulson, pp. 197-209. Center for Ancient Studies, University of Minnesota, Minneapolis.

1986 Description and Comparison of the Skeleton (with J. O. Kelley). In The Wadi Kubbaniya Skeleton: A Late Paleolithic Burial from Southern Egypt, edited by A. E. Close, pp. 53-70. Southern Methodist University Press, Dallas.

1986 Health and Stress in an Early Bronze Age Population (with S. C. Bisel). In Ancient Anatolia, Aspects of Change and Cultural Development, Essays in Honor of Machteld J. Mellink, edited by J. V. Canby, E. Porada, B. S. Ridgway, and T. Stech, pp. 12-30. University of Wisconsin Press, Madison.

1986 The Physical Identity of the Trojans. In Troy and the Trojan War, A Symposium Held at Bryn Mawr College October 1984, edited by M. J. Mellink, pp. 63-76. Department of Classical and Near Eastern Archaeology, Bryn Mawr College Press, Bryn Mawr, Pennsylvania.

1987 Life Stresses of Slavery (with J. O. Kelley). American Journal of Physical Anthropology 74:199-211.

1987 Life Stresses of the Free Black Community as Represented by the First African Baptist Church, Philadelphia, 1823-1841 (with J. O. Kelley, M. Parrington, and S. Pinter). American Journal of Physical Anthropology 74:213-229. 